\title{
Impacts of Topsoil Removal due to Brick Manufacturing on Soil Properties of Agricultural Lands at Nagarpur Upazila of Tangail, Bangladesh
}

\author{
Utpol Kumar $^{1 *}$, Md. Hosenuzzaman ${ }^{2}$, Samina Nasrin Borna ${ }^{3}$, Diti Akter ${ }^{3}$ and \\ Md. Sirajul Islam ${ }^{3}$
}

\author{
${ }^{1}$ Soil Resource Development Institute, Ministry of Agriculture, Tangail, Bangladesh \\ ${ }^{2}$ Department of Soil Science, Bangladesh Agricultural University, Mymensingh-2202, Bangladesh. \\ ${ }^{3}$ Department of Environmental Science and Resource Management, Mawlana Bhashani Science and Technology University, Tangail-1902, \\ Bangladesh \\ *Corresponding author
}

\begin{abstract}
The study was conducted to compare soil nutrients status between agricultural land and top soil removal land from surrounding area of brick field due to brick manufacturing at Nagarpur region, Tangail, Bangladesh, during the period of July to December 2018. Total 30 samples were collected from three different brickfields area namely S1, S2, S3. Among them 10 samples were collected from each site whereas 5 samples from productive agricultural land and 5 samples from removal land at a depth $0-15 \mathrm{~cm}$. The overall study stated that the status of \% organic matter $(O M)$, total nitrogen $(N)$, available phosphorus $(P)$, exchangeable potassium $(\mathrm{K})$, available sulfur $(\mathrm{S})$, available zinc $(\mathrm{Zn})$, available boron $(\mathrm{B})$, magnesium $(\mathrm{Mg})$ and calcium $(\mathrm{Ca})$ were decreased in top soil removal land. The mean status of these nutrients were very low (0.92\%), very low

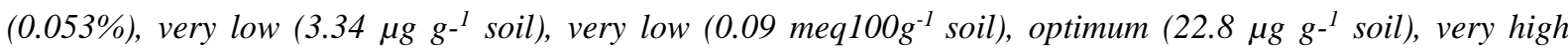
$\left(3.80 \mu \mathrm{g} \mathrm{g}^{-1}\right.$ soil), low $\left(0.28 \mu \mathrm{g} \mathrm{g-}^{1}\right.$ soil), optimum $\left(1.26 \mathrm{meq}^{100 \mathrm{~g}^{-1}}\right.$ soil) and very low $\left(1.25 \mathrm{meq}^{100 \mathrm{~g}^{-1}}\right.$ soil) respectively in top soil removal land. On the other hand these were medium (2.49\%), low (0.14\%), very low

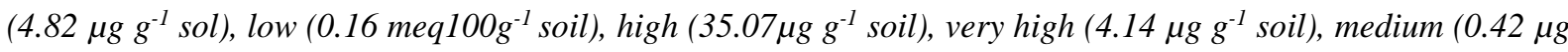
g-1 soil), very high $\left(4.35 \mathrm{meq}^{100 \mathrm{~g}^{-1}}\right.$ soil) and high $\left(6.36 \mathrm{meq} 100 \mathrm{~g}^{-1}\right.$ soil) respectively in adjacent agricultural land. The cropping patterns of the agricultural land were Mustard-Boro rice-Jute but Fellow-Fellow-Jute in top soil removal land. The economic analysis showed a gross of 1845.24 US\$ net loss per hectare per annum of crops yield due to top soil removal for brick manufacturing in the brick field.
\end{abstract}

Keywords-brickfield, soil nutrients, top soil, agricultural land.

\section{INTRODUCTION}

Soil is a natural resource for which there is no substitute. It is a thin covering over the land consisting of a mixture of minerals, organic materials, living organisms, air and water that together support the growth of plant life (Huq and Shoaib, 2013). Topsoil, is one of the earth's most vital resources and the upper surface of the earth's crust. It is naturally deposited material that mixes rich humus with minerals and composted material (Tucker et al., 1995). But topsoil degradation is the most serious problems in the world today as a result of natural or anthropogenic factors, because of their adverse effects on agriculture and the life on earth (Eswaran et al., 1999; Khan et al., 2007). Brick burning is one of the principal agents of topsoil degradation (Rahman and Khan, 2001). Brick kilns remove topsoil for brick making. The negative impact of topsoil removal results in reduction in agricultural output and increases cost of replacing the nutrients lost (Das, 2015). Brick are destroying large area of land every year especially in Bangladesh (Rahman and Khan, 2001). These affected areas are expanding rapidly due to the increase in brick production (IUSS, 2002). There are about 6,000 brick manufacturers in Bangladesh which produce about 18 billion pieces of brick a year (Rahman, 2012). 
In the Nagarpur upazila, soil is mainly used for agricultural production. The soil quality is decreasing due to the negative effects of brickfields. The temperature surroundings the brickfield is very high, for this reason rust increases in paddy in the study area and agricultural production is decreasing year to year in this area. Top soils are used for making bricks and that causes loss of nutrients in the agricultural land and decreases soil fertility in the study area. According to these points of view, the study was conducted to fulfill the following objectives:

i) To compare the soil nutrients status between the top soil removal and productive agricultural land, and

ii) To estimate net economic loss of agriculture products due to top soil removal for brick manufacturing in the brick field.

\section{MATERIALS AND METHODS}

\section{Study area}

The study area is located in Nagarpur upazila under Tangail district, Bangladesh which is located between $23^{\circ} 58^{\prime}$ to $24^{\circ} 10^{\prime} \mathrm{N}$ latitudes and $89^{\circ} 46^{\prime}$ to $90^{\circ} 01^{\prime} \mathrm{E}$ longitudes. The total area of Nagarpur upazila is 266.77 sq. $\mathrm{km}$. It is bounded by Tangail sadar and Delduar upazila on the north, Daulatpur (Manikganj) and Saturia upazila on the south, Mirzapur and Dhamrai upazila on the east, Chauhali and Shahjadpur upazila on the west.

\section{Sample collection}

A total of 30 samples were collected from three different brick field of three union (Shahabatpur-S1, Nagarpur-S2 and Bekra-S3) of Nagarpur upazila of Tangail. Ten (10) samples were collected from each union. Among them 5 samples were from productive agricultural land and 5 samples were from top soil removal land adjacent to brickfield. Soil samples A-1, A-2, A-3, A-4, A-5, A-6, A-7, A-8, A-9, A-10, A-11, A-12, A-13, A-14 and A-15 denoted the points of soil samples which were collected from agricultural land and R-1, R-2, R-3, R-4, R-5, R-6, R-7, R8, R-9, R-10, R-11, R-12, R-13, R-14 and R-15 from top soil removal land surrounding brick fields, respectively. The samples were scraped from the top to bottom (0-15 $\mathrm{cm}$ ) by auger in nine points of a land and made it a composite sample. About $1000 \mathrm{~g}$ of soils were collected for a representative sample. Then air dried for 7 days at room temperature. Visible roots and debris were removed. The larger and massive aggregates were broken by wooden hammer. Then screened to pass through a $2 \mathrm{~mm}$ stainless steel sieve and again screened to pass through a $0.5 \mathrm{~mm}$ sieve. The sieved samples were mixed thoroughly for making composite samples. Soil samples were preserved in polythene bags and labeled properly showing the location, sample number and date of collection.

\section{Sample analysis}

The $\mathrm{pH}$ was measured by Glass Electrode $\mathrm{pH}$ Meter with 1: 2.5 soil-water ratios (Jackson, 1962). The organic matter was determined by Walkley and Black's wet oxidation method (Huq and Alam, 2005).Total nitrogen was analyzed by micro Kjeldahl method (Bremner and Mulvaney, 1982). The available phosphorus was determined by the Olsen method (Satter et al., 1987). The available potassium was determined by ammonium acetate extraction method (Satter et al., 1987). The available sulfur was analyzed by calcium chloride extraction method (Williums and Steinbergs, 1959). The available zinc was determined by DTPA (Diethylene-tri-amine penta acetic acid) method (Roberts et al., 1971). The available boron was determined by azomethine-H method (Page et al., 1982). The calcium and magnesium were analyzed by EDTA (Ethylene-diamine tetra acetic acid) titration method (Huq and Alam, 2005). The status of the soil properties was interpreted according to Fertilizer Recommendation Guide 2018 (BARC, 2018). Mean, standard error and standard deviation were calculated by using Microsoft Excel programme.

\section{RESULTS AND DISCUSSIONS}

\section{pH}

The mean value of $\mathrm{pH}$ in agricultural land sample was slightly acidic (6.19) and in top soil removal land was slightly alkaline (7.54) (Fig. 1). The values in agricultural land samples were ranged from 5.65 to 7.07 (slightly acidic to neutral) and in top soil removal land samples were found 7.3 to 7.8 (neutral to slightly alkaline) (Table 1). Islam et al. (2015) reported that the $\mathrm{pH}$ values of the samples ranged from 6.52 to 7.23 in the burnt soils and from 5.62 to 6.15 in the unburnt soils. All kinds of crops are grown well in the $\mathrm{pH}$ range of 5.6-7.3 (neutral), because all types of essential nutrients are available in this range (BARC, 2018). 


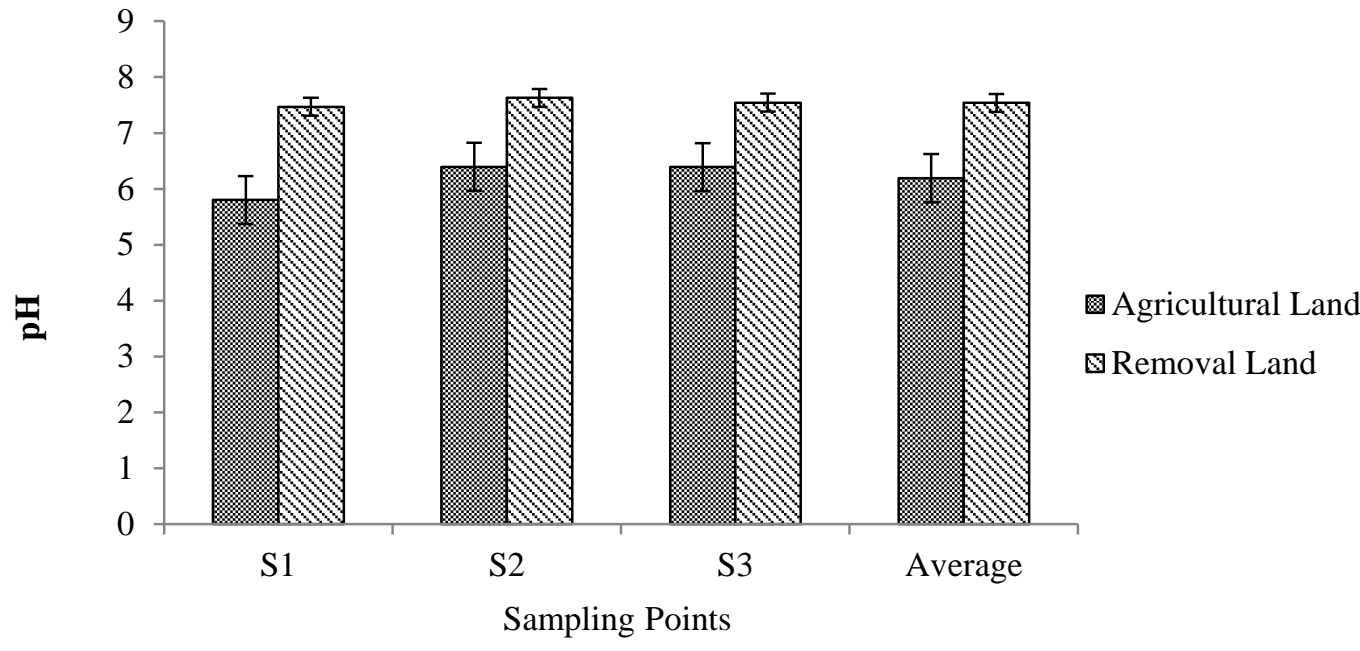

Figure 1 Comparison of pH between agricultural and top soil removal lands at different brick fields.

Table 1 Comparison of soil fertility status in productive agricultural and top soil removal lands

\begin{tabular}{|c|c|c|c|c|c|}
\hline Soil nutrients & Site & $\begin{array}{c}\text { Agricultural land } \\
\text { Average* }\end{array}$ & Range & $\begin{array}{c}\text { Removal land } \\
\text { Average* }\end{array}$ & Range \\
\hline \multirow{5}{*}{$\mathrm{pH}$} & S1 & 5.8 & \multirow{4}{*}{$5.65-7.07$} & 7.46 & \multirow{4}{*}{$7.3-7.8$} \\
\hline & $\mathrm{S} 2$ & 6.39 & & 7.63 & \\
\hline & $\mathrm{S} 3$ & 6.39 & & 7.54 & \\
\hline & Mean \pm SD & $6.19 \pm 0.43$ & & $7.54 \pm 0.16$ & \\
\hline & Status & Slightly acidic & Slightly acidic -Neutral & Slightly alkaline & Neutral - Slightly alkaline \\
\hline \multirow{5}{*}{$\begin{array}{c}\text { \%Organic } \\
\text { Matter (OM) }\end{array}$} & $\mathrm{S} 1$ & 2.39 & \multirow{4}{*}{$1.65-3.3$} & 0.98 & \multirow{4}{*}{$0.4-2.44$} \\
\hline & $\mathrm{S} 2$ & 2.54 & & 0.82 & \\
\hline & S3 & 2.56 & & 0.97 & \\
\hline & Mean \pm SD & $2.49 \pm 0.40$ & & $0.92 \pm 0.42$ & \\
\hline & Status & Medium & Low-Medium & Very low & Very low - Medium \\
\hline \multirow{5}{*}{$\begin{array}{c}\text { \% Total } \\
\text { Nitrogen }(\mathrm{N})\end{array}$} & $\mathrm{S} 1$ & 0.14 & & 0.056 & \\
\hline & $\mathrm{S} 2$ & 0.14 & $0.08-0.18$ & 0.046 & $0.03-0.12$ \\
\hline & S3 & 0.15 & & 0.058 & \\
\hline & Mean \pm SD & $0.14 \pm 0.02$ & & $0.053 \pm 0.025$ & \\
\hline & Status & Low & Very low - Low & Very low & Very low - Low \\
\hline \multirow{5}{*}{$\begin{array}{c}\text { Available } \\
\text { Phosphorous } \\
(\mathrm{P}) \\
\left(\mu \mathrm{g} \mathrm{g}^{-1} \text { soil) }\right.\end{array}$} & S1 & 3.50 & & 3.89 & \\
\hline & $\mathrm{S} 2$ & 4.14 & $1.4-8.7$ & 3.49 & $1.2-5.96$ \\
\hline & S3 & 6.81 & & 2.63 & \\
\hline & Mean \pm SD & $4.82 \pm 2.30$ & & $3.34 \pm 1.36$ & \\
\hline & Status & Low & Very low - Low & Very Low & Very low - Low \\
\hline \multirow[b]{2}{*}{ Exchangeable } & $\mathrm{S} 1$ & 0.15 & & 0.08 & \\
\hline & $\mathrm{S} 2$ & 0.16 & $0.11-0.23$ & 0.09 & $0.03-0.19$ \\
\hline
\end{tabular}


International Journal of Environment, Agriculture and Biotechnology, 5(3)

May-Jun, 2020 / Available: https://ijeab.com/

\begin{tabular}{|c|c|c|c|c|c|}
\hline \multirow{3}{*}{$\begin{array}{l}\text { Potassium (K) } \\
\text { (meq100g-1 } \\
\text { soil) }\end{array}$} & S3 & 0.17 & & 0.10 & \\
\hline & Mean \pm SD & $0.16 \pm 0.03$ & & $0.09 \pm 0.04$ & \\
\hline & Status & Low & Low - Medium & Very low & Very low - Medium \\
\hline \multirow{5}{*}{$\begin{array}{l}\text { Available } \\
\text { Sulfur }(\mathrm{S}) \\
\left(\mu \mathrm{g} \mathrm{g}^{-1} \text { soil }\right)\end{array}$} & S1 & 40.8 & & 24.16 & \\
\hline & $\mathrm{S} 2$ & 31.71 & $23.37-47.95$ & 21.62 & $15.2-37.43$ \\
\hline & S3 & 32.69 & & 22.61 & \\
\hline & Mean \pm SD & $35.07 \pm 6.85$ & & $22.8 \pm 7.25$ & \\
\hline & Status & High & Optimum - Very high & Optimum & Medium - High \\
\hline \multirow{5}{*}{$\begin{array}{c}\text { Available Zinc } \\
\text { (Zn) } \\
\left(\mu \mathrm{g} \mathrm{g}^{-1} \text { soil }\right)\end{array}$} & S1 & 4.46 & & 4.06 & \\
\hline & S2 & 4.1 & $3.3-5.9$ & 3.92 & $2.9-5.1$ \\
\hline & S3 & 3.86 & & 3.44 & \\
\hline & Mean \pm SD & $4.14 \pm 0.74$ & & $3.80 \pm 0.64$ & \\
\hline & Status & Very high & Very high & Very high & Very high \\
\hline \multirow{5}{*}{$\begin{array}{l}\text { Available } \\
\text { Boron (B) } \\
\left(\mu \mathrm{g} \mathrm{g}^{-1} \text { soil }\right)\end{array}$} & S1 & 0.42 & & 0.23 & \\
\hline & S2 & 0.40 & $0.33-0.51$ & 0.29 & $0.18-0.43$ \\
\hline & S3 & 0.43 & & 0.32 & \\
\hline & Mean \pm SD & $0.42 \pm 0.05$ & & $0.28 \pm 0.07$ & \\
\hline & Status & Medium & Medium - Optimum & Low & Low - Medium \\
\hline \multirow{5}{*}{$\begin{array}{l}\text { Calcium }(\mathrm{Ca}) \\
\left(\mathrm{meq} 100 \mathrm{~g}^{-1}\right. \\
\text { soil) }\end{array}$} & S1 & 6.4 & & 1.46 & \\
\hline & S2 & 6.4 & $5-7.5$ & 1.14 & $0.6-2$ \\
\hline & S3 & 6.3 & & 1.15 & \\
\hline & Mean \pm SD & $6.36 \pm 0.93$ & & $1.25 \pm 0.44$ & \\
\hline & Status & High & Optimum - high & Very low & Very low - Low \\
\hline \multirow{5}{*}{$\begin{array}{l}\text { Magnesium } \\
(\mathrm{Mg}) \\
\left(\mathrm{meq} 100 \mathrm{~g}^{-1}\right. \\
\text { soil) }\end{array}$} & S1 & 4.36 & & 1.42 & \\
\hline & S2 & 4.03 & $3.3-5.5$ & 1.35 & $0.5-2.5$ \\
\hline & S3 & 4.66 & & 1.02 & \\
\hline & Mean \pm SD & $4.35 \pm 0.78$ & & $1.26 \pm 0.57$ & \\
\hline & Status & Very high & Very high & Optimum & Low - Very high \\
\hline
\end{tabular}

Note: $*$ = Average of five samples, SD = Standard Deviation.

\section{Organic Matter (OM)}

The mean organic matter $(\mathrm{OM})$ status of agricultural land was medium $(2.49 \%)$ but in top soil removal land it was very low (0.92\%) (Fig. 2). The organic matter (OM) contents of agricultural land samples were ranged from 1.65 to $3.3 \%$ (low to medium) and of removal land samples were ranged from 0.4 to $1.99 \%$ (very low to medium) (Table 1). SRDI (2018) reported that the OM values of Nagorpur agricultural soils ranged from 2.20 to $2.70 \%$, respectively. Above $3.4 \%$ (high) $\mathrm{OM}$ content is the suitable for the most of the agricultural crop production (BARC, 2018). 


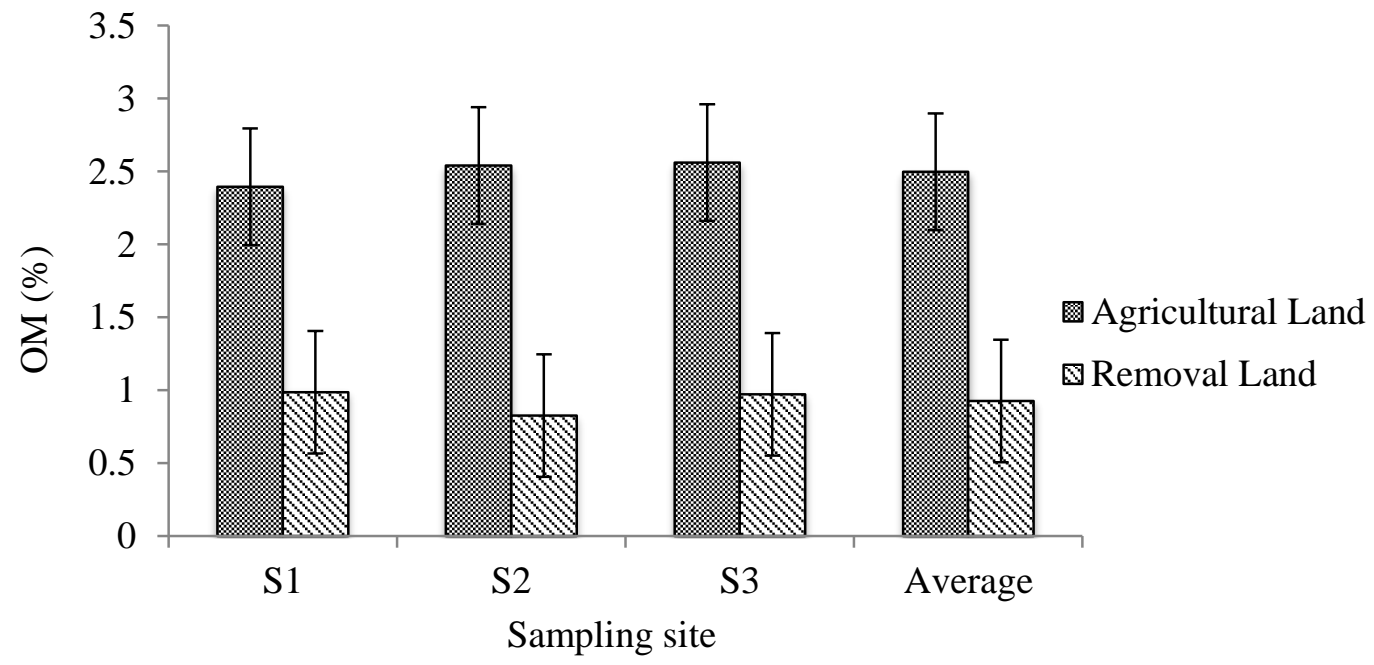

Figure 2 Comparison of organic matter (OM) contents between agricultural and removal lands at different brick fields.

\section{Total Nitrogen (N)}

The mean total nitrogen $(\mathrm{N})$ status of agricultural land was low $(0.14 \%)$ but in top soil removal land it was very low $(0.053 \%)$ (Fig. 3). The total nitrogen $(\mathrm{N})$ contents of agricultural lands were ranged from 0.08 to $0.18 \%$ (very low to low) and of removal lands were ranged from 0.03 to $0.12 \%$ (very low to low) (Table 1$)$. Optimum $(>0.27 \%) \mathrm{N}$ status is the suitable for all kinds of crop production (BARC, 2018). Hossain et al. (2003) observed that the total $\mathrm{N}$ content decreased with increasing the depth of soils. In the Old Brahmaputra Floodplain soil, the nitrogen was varied from 0.038 to $0.100 \%$ and in Madhupur tract from 0.010 to $0.082 \%$ under different cropping patterns and tillage.

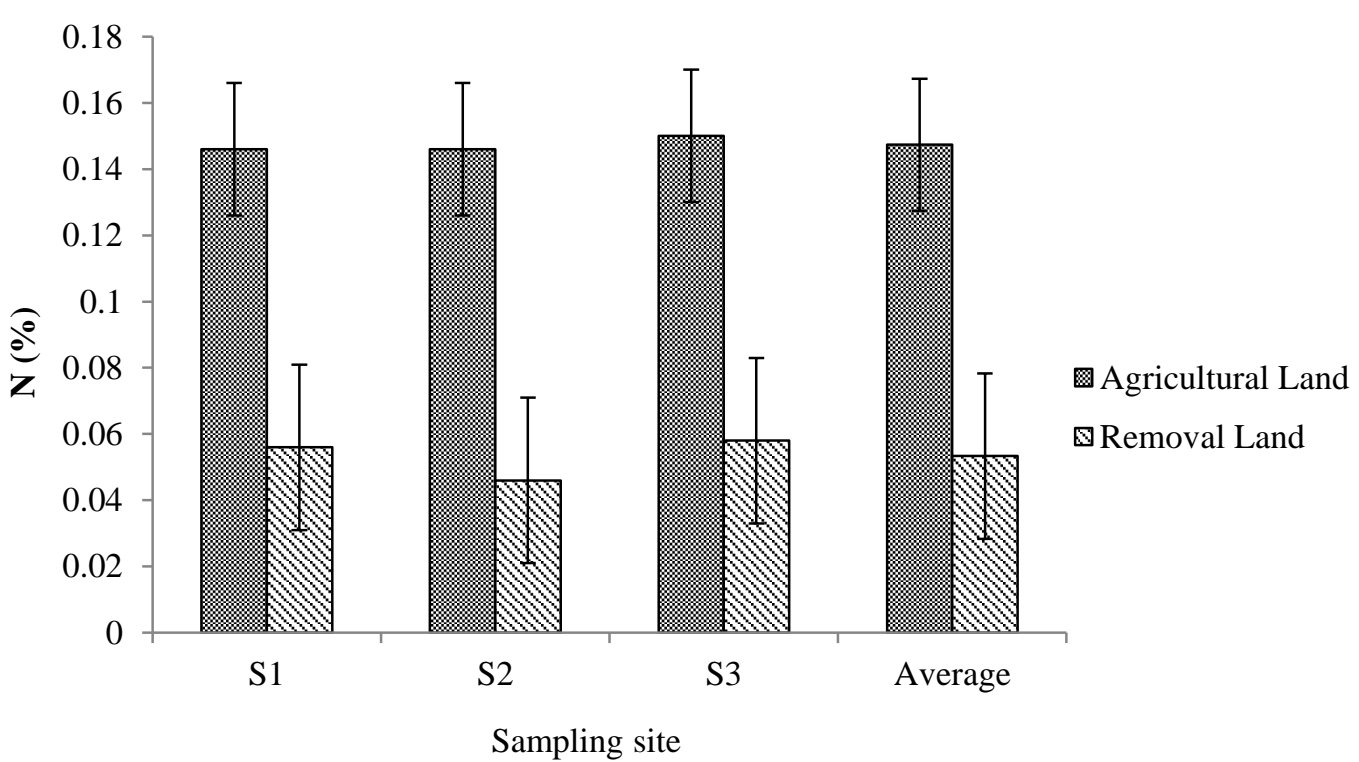

Figure 3 Comparison of total nitrogen $(N)$ contents between agricultural and top soil removal lands at different brick fields

\section{Available Phosphorous (P)}

The mean available phosphorous (P) status of agricultural land was low (4.827 $\mu \mathrm{g} \mathrm{g}^{-1}$ soil) but in top soil removal land it was very low (3.34 $7 \mu \mathrm{g} \mathrm{g}^{-1}$ soil) (Fig. 4). The available phosphorous (P) contents of agricultural lands were ranged from 1.4 to $8.7 \mu \mathrm{g} \mathrm{g}^{-1}$ soil (very low to low) and of top soil removal lands were ranged from 1.2 to5.96 $\mu \mathrm{g} \mathrm{g}^{-1}$ soil (very low to low) (Table 1). Prabpai et al. 
(2007) found that available phosphorus, plant macronutrient constituent, in landfill soil was at a high to very high level; 21-26 mg kg-1. BARC (2018) reported that the optimum $\left(>11.26 \mu \mathrm{g} \mathrm{g}^{-1}\right.$ soil) status of available $\mathrm{P}$ value is suitable for all kinds of crop production.

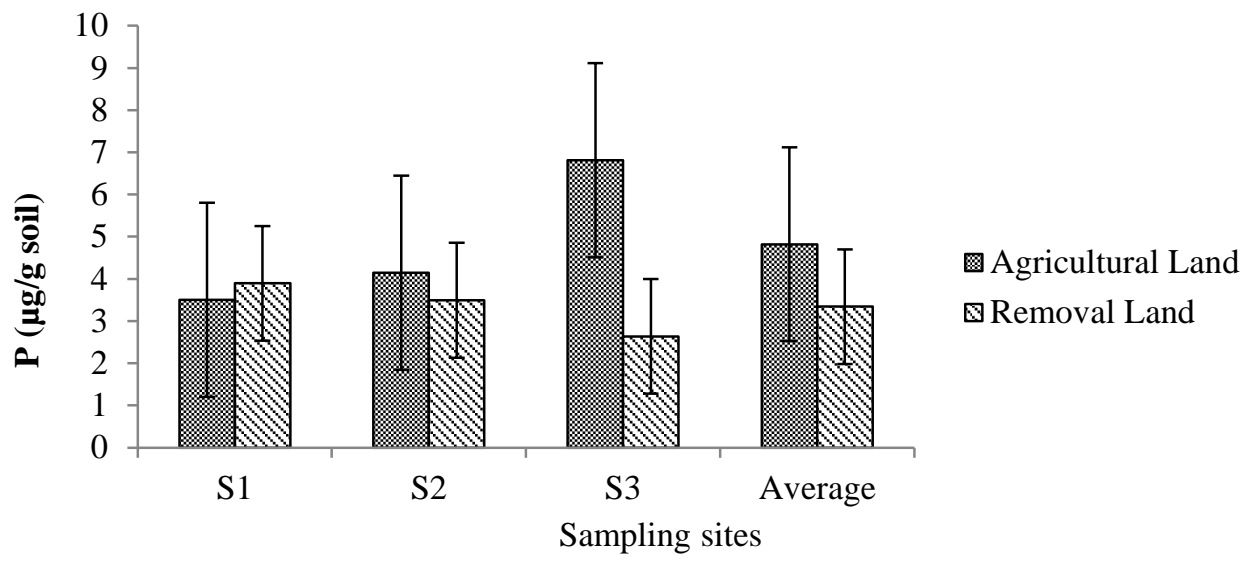

Figure 4 Comparison of phosphorous $(P)$ concentrations between agricultural and removal lands at different sampling sites

\section{Exchangeable Potassium (K)}

The mean exchangeable potassium (K) status of agricultural land was low $\left(0.16\right.$ meq $100 \mathrm{~g}^{-1}$ soil $)$ but it was very low $\left(0.09 \mathrm{meq} 100 \mathrm{~g}^{-1}\right.$ soil $)$ in top soil removal soil (Fig. 5).The potassium (K) contents of agricultural lands were ranged from 0.11 to 0.23 meq $100 \mathrm{~g}^{-1}$ (low to medium) and of top soil removal lands were ranged from 0.03 to
0.19 meq $100 \mathrm{~g}^{-1}$ soil (very low to medium) (Table 1). Singh et al. (2000) reported that the exchangeable $\mathrm{K}$ of old alluvial soils of some basin was 0.04 to $0.87 \mathrm{meq}_{100 \mathrm{~g}^{-1}}$

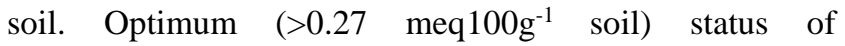
exchangeable $\mathrm{K}$ is the suitable for all kinds of agricultural crops production (BARC, 2018).

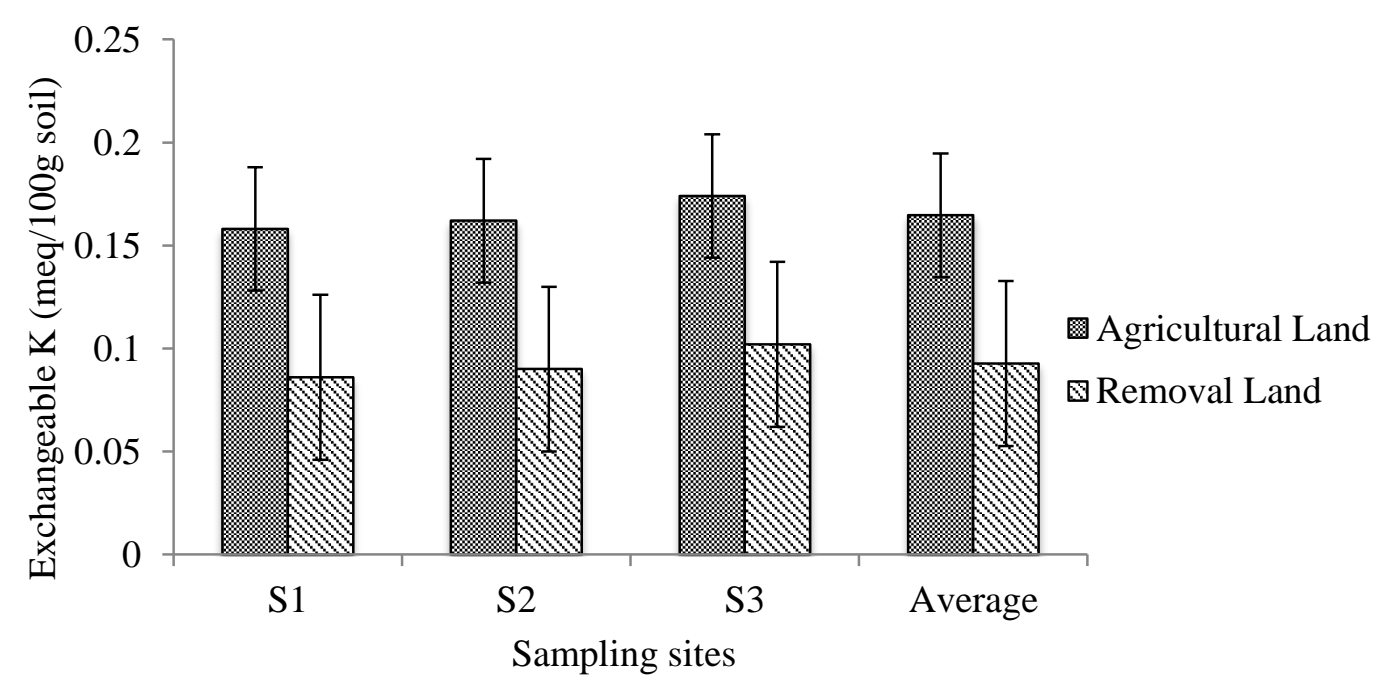

Figure 5 Comparison of potassium $(K)$ concentrations between agricultural and removal lands at different sampling sites

\section{Available Sulfur (S)}

The mean available sulfur (S) status of agricultural land was high (35.07 $\mu \mathrm{g} \mathrm{g}^{-1}$ soil) but it was optimum $\left(22.8 \mu \mathrm{g} \mathrm{g}^{-}\right.$ ${ }^{1}$ soil) in top soil removal land (Fig. 6). The available $\mathrm{S}$ contents of agricultural lands were ranged from 23.37 to $47.95 \mu \mathrm{g} g-1$ soil and of top soil removal lands were ranged from 15.2 to $37.43 \mu \mathrm{g} \mathrm{g}^{1}{ }^{1}$ soil (Table 1 ). Optimum (>22.5 $\mu \mathrm{g} g-1$ soil) status of $\mathrm{S}$ is suitable for all kinds of agricultural crops production (BARC, 2018). 


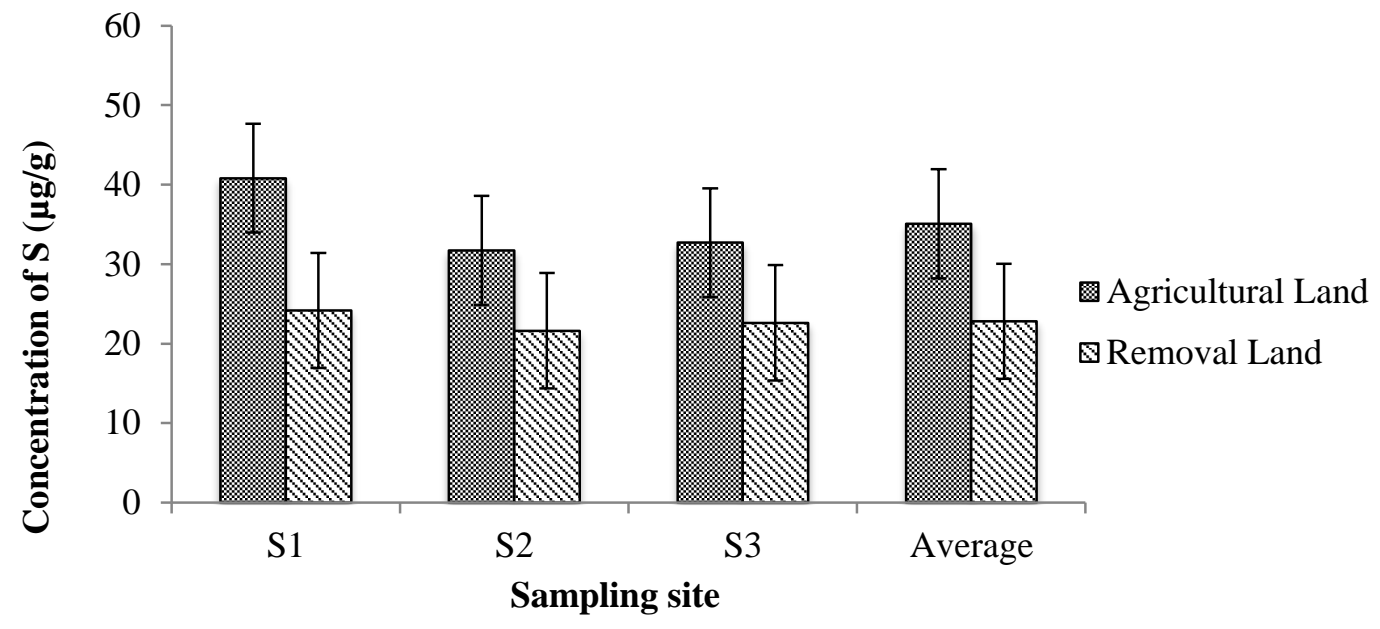

Figure 6 Comparison of sulfur $(S)$ concentrations between agricultural and top soil removal lands at different sampling sites

\section{Available Zinc (Zn)}

The mean available zinc $(\mathrm{Zn})$ status of agricultural land and top soil removal land were very high (4.14 and $3.80 \mu \mathrm{g}$ $\mathrm{g}^{-1}$ soil respectively) (Fig. 7). The available $\mathrm{Zn}$ contents of agricultural lands were ranged from 3.3 to $5.9 \mu \mathrm{g} \mathrm{g}^{-1}$ (very high) and of top soil removal land samples were ranged from 2.9 to $5.1 \mathrm{\mu g} \mathrm{g-}^{1}$ (very high) also (Table 1). Islam et al. (2015) found total $\mathrm{Zn}$ content ranged from 2.030 to $2.089 \mathrm{ppm}$ in the burnt and from 2.112 to $2.991 \mathrm{ppm}$ in the unburnt soil. Optimum ( $>0.1 .35 \mu \mathrm{g} \mathrm{g}^{-1}$ soil) status of $\mathrm{Zn}$ is suitable for all kinds of agricultural crops production (BARC,2018).

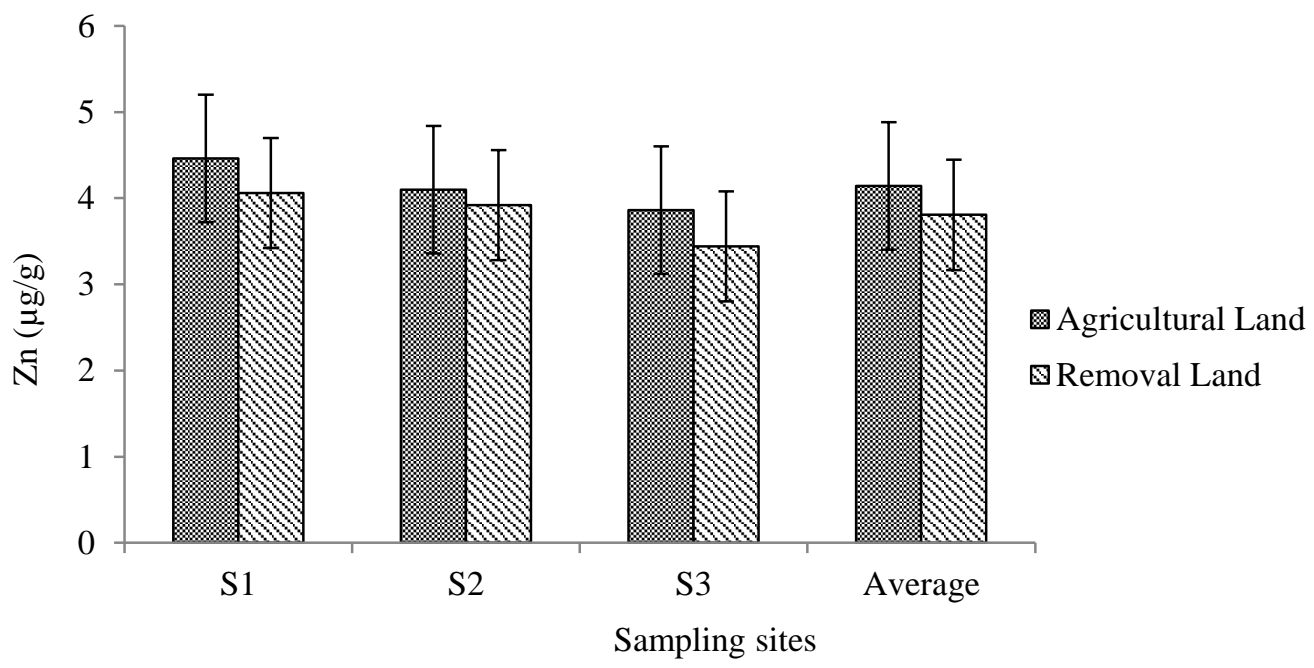

Figure 7 Comparison of zinc $(\mathrm{Zn})$ concentrations between agricultural and removal lands at different sampling sites

\section{Available Boron (B)}

The mean available boron (B) status of agricultural land was medium $\left(0.42 \mu \mathrm{g} \mathrm{g}^{-1}\right.$ soil $)$ but it was low $\left(0.28 \mu \mathrm{g} \mathrm{g}^{-1}\right.$ soil) in top soil removal land (Fig. 8). The available B contents of agricultural lands were ranged from 0.33 to
$0.51 \mu \mathrm{g} \mathrm{g}^{-1}$ soil (medium to optimum) and of top soil removal lands were ranged from 0.18 to $0.43 \mu \mathrm{g} \mathrm{g}^{-1}$ soil (low to medium) (Table 1$)$. Optimum $\left(>0.45 \mu \mathrm{g} \mathrm{g}^{-1}\right.$ soil) status of $\mathrm{B}$ is suitable for all kinds of agricultural crops production (BARC, 2018). 


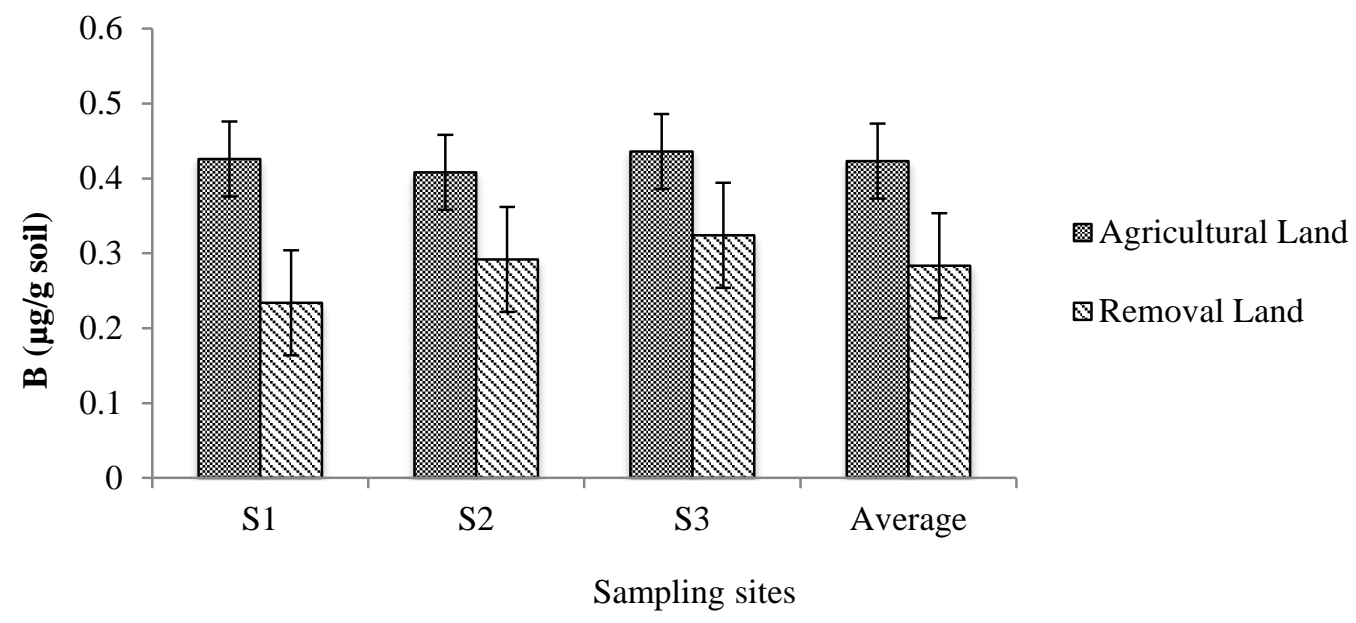

Figure 8 Comparison of boron $(B)$ concentrations between agricultural and removal lands at different sampling sites

\section{Calcium (Ca)}

The mean calcium $(\mathrm{Ca})$ status of agricultural land was high (6.36 meq $100 \mathrm{~g}^{-1}$ soil) but very low $\left(1.25 \mathrm{meq} 100 \mathrm{~g}^{-1}\right.$ soil) in top soil removal land (Fig. 9). The $\mathrm{Ca}$ contents of agricultural lands were ranged from 5 to 7.5 meq $100 \mathrm{~g}^{-1}$ soil (optimum to high) and in top soil removal land it was ranged from 0.6 to 2 meq $100 \mathrm{~g}^{-1}$ soil (very low to low) (Table 1). Optimum ( $>4.5$ meq $100 \mathrm{~g}^{-1}$ soil) status of $\mathrm{Ca}$ is the suitable for all kinds of agricultural crops production (BARC, 2018).

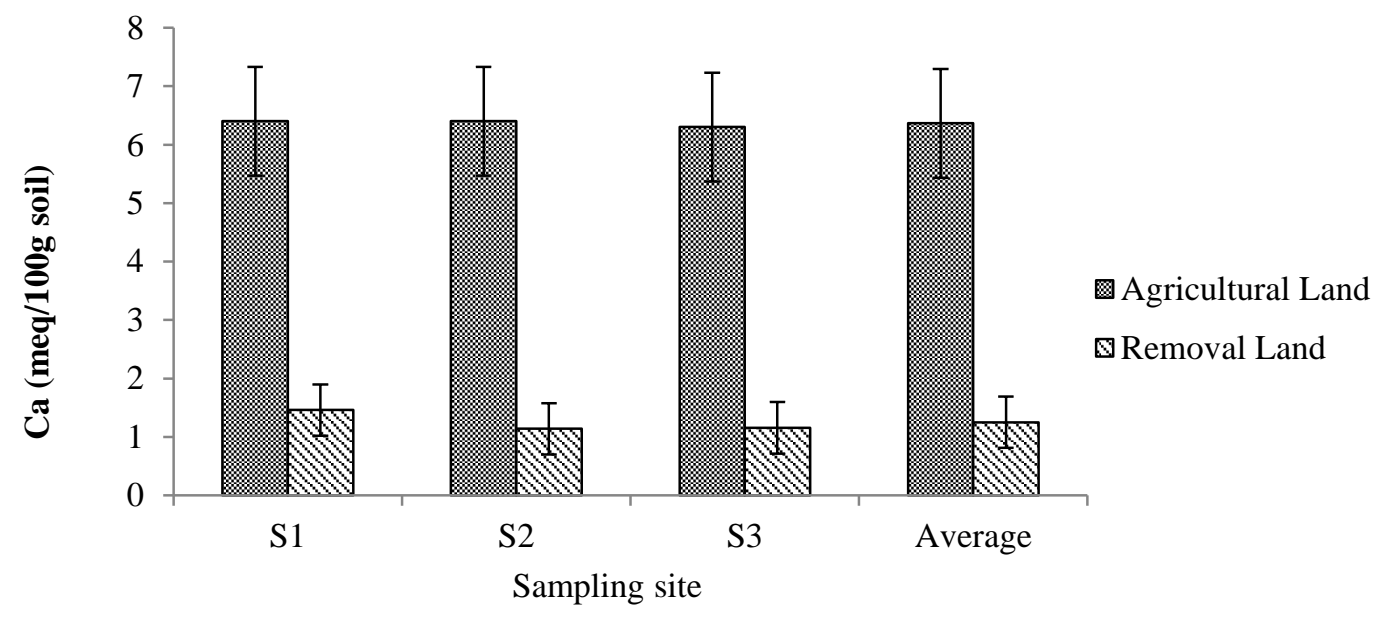

Figure 9 Comparison of calcium $(\mathrm{Ca})$ concentrations between agricultural and removal lands at different sampling sites

\section{Magnesium (Mg)}

The mean magnesium $(\mathrm{Mg})$ status of agricultural land was very high ( 4.35 meq $100 \mathrm{~g}^{-1}$ soil) but it was optimum $(1.26$ 35 meq100g-1 soil) in top soil removal land (Fig. 10). The $\mathrm{Mg}$ contents of agricultural lands were ranged from 3.3 to
$5.535 \mathrm{meq} 100 \mathrm{~g}^{-1}$ soil and of top soil removal lands were

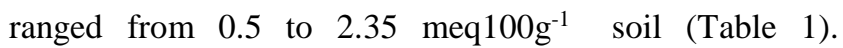
Optimum (>1.125 meq $100 \mathrm{~g}^{-1}$ soil) status is suitable for all kinds of agricultural crops production (BARC, 2018). 


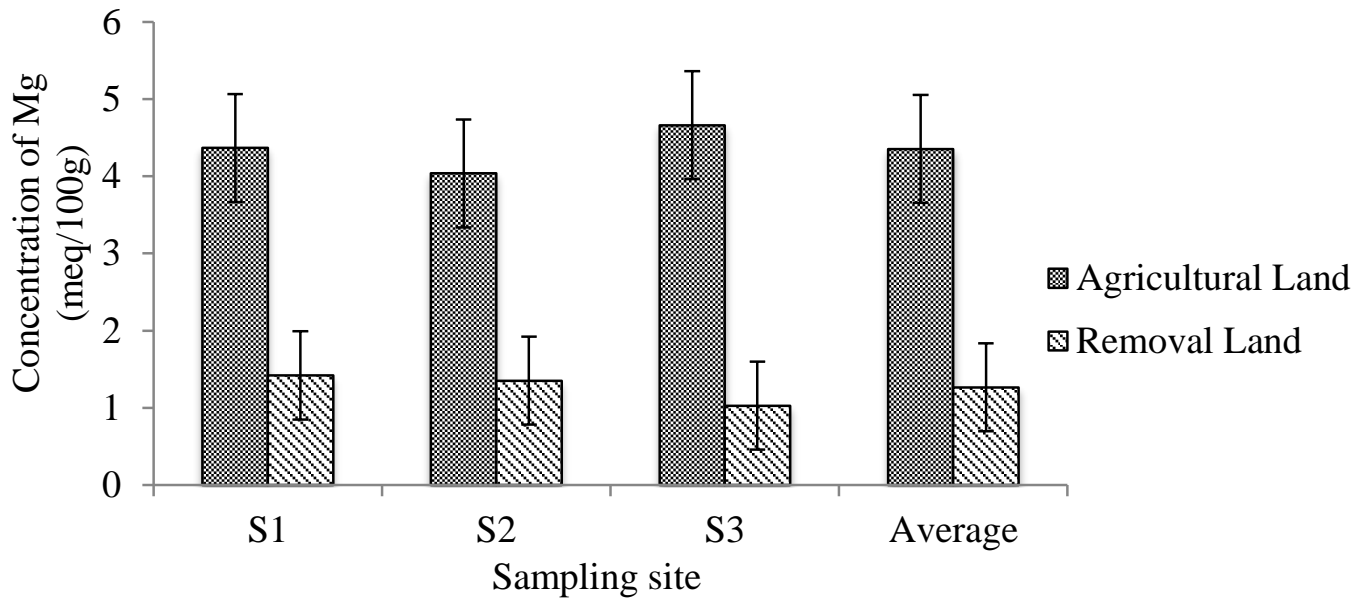

Figure 10 Comparison of magnesium $(\mathrm{Mg})$ concentrations between agricultural and removal lands at different sampling sites.

\section{Economic analysis:}

Table 2 Land use pattern of the study area.

\begin{tabular}{|c|c|c|}
\hline Site & Category of land & Cropping pattern \\
\hline \multirow{2}{*}{ Site - 1} & Productive agricultural land & Boro-Jute-Mustard \\
\cline { 2 - 3 } & Top soil Removal land & Fallow-Jute-Fallow \\
\hline \multirow{2}{*}{ Site -2} & Productive agricultural land & Boro-Jute-Mustard \\
\cline { 2 - 3 } & Top soil Removal land & Fallow-Jute-Fallow \\
\hline \multirow{2}{*}{ Site -3} & Productive agricultural land & Boro-Jute-Mustard \\
\cline { 2 - 3 } & Top soil Removal land & Fallow-Jute-Fallow \\
\hline
\end{tabular}

The result of the Table 2 showed that cropping pattern was been changed due to removal of top soil from the productive agricultural land. Three crops were been cultivated in agricultural land but only one crop was been cultivated from top soil removal land. This might be due to changing of land type. Due to top soil removal, medium high land was been converted to medium low land. Nutrient mining was also a factor of decreasing crops.

Table 3 Analysis of economic loss due to removal of top soil in the brick field from the productive agricultural land

\begin{tabular}{|c|c|c|c|c|c|}
\hline Category of land & Name of the crops & Yield (ton/ha) & Market price (US\$./kg) & Amount (US\$) & Total(US\$) \\
\hline \multirow{3}{*}{$\begin{array}{l}\text { Productive agricultural } \\
\text { land }\end{array}$} & Jute & 3 & 0.36 & 1071.43 & \multirow{3}{*}{2738.10} \\
\hline & Mustard & 1 & 0.60 & 595.24 & \\
\hline & Boro rice & 6 & 0.18 & 1071.43 & \\
\hline Top soil removal land & Jute & 2.5 & 0.36 & 892.86 & 892.86 \\
\hline \multicolumn{5}{|c|}{ Net Economic loss due to removal of top soil } & 1845.24 \\
\hline
\end{tabular}

Table 3 showed that total income was been come 2738.10 US\$ per year per hectare from productive agricultural land. On the other hand, only 892.86 US\$ per year per hectare was been come from top soil removal land. That means, net economic lose found from the top soil removal land was 1845.24 US\$ per year per hectare.

Result showed a remarkable variation of economic earning of crop production between productive agricultural land 
and top soil removal land. The main reason of the economic loss might be changing of cropping pattern and mining of nutrients from the soil due to removal of top soil from productive agricultural land for the brick manufacturing at the study area.

\section{CONCLUSION}

From the study, it was clearly identified that the mean value of $\mathrm{pH}$, was lower in productive agricultural land than in top soil removal land. The mean value of organic matter

$(\mathrm{OM})$, nitrogen $(\mathrm{N})$, phosphorus $(\mathrm{P})$, potassium $(\mathrm{K})$, sulfur $(\mathrm{S})$, zinc $(\mathrm{Zn})$, boron $(\mathrm{B})$ magnesium $(\mathrm{Mg})$ and calcium (Ca) were decreased at all sites of top soil removal land and lower than productive agricultural land. Finally, Nutrient status, crop yield and economic benefit were been declined tremendously as a consequence of top soil removal due to brick manufacturing. Therefore, based on the findings of the study it was recommended that proper initiatives should be taken by the Government to apply the rules and regulations to protect the productive agricultural land from nutrient mining, brickfield management and it should be ensured that farmers (land owners) should not sold their top soil from the productive agricultural land. It was also recommended that brick fields should be built far from the agricultural land.

\section{REFERENCES}

[1] BARC. (2018). Fertilizer Recommendation Guide2018. Bangladesh Agricultural Research Council (BARC), Ministry of Agricultur,Farmgate, Dhaka.

[2] Bremner J.M., Mulvaney C.S. (1982). Nitrogen-Total. In: Methods of Soil Analysis. Part 2. 2nd ed. A.L. Page, R.H. Miller and D.R. Keeney (Eds.), pp. 595-623. Madison, WI: ASA

[3] Das, R. (2015). Causes and Consequences of Land Degradation in and around the Brick Kilns of Khejuri CD Blocks over Coastal Medinipur in West Bengal, International Journal of Innovative Research and Development, 4(2): 285

[4] Eswaran, H. (1999). Recommendation in the proceedings of the 2nd international conference on land degradation. January 25-29, KhonKaen, Thailand, 9 pp.

[5] Hossain, A., Hossain, A.K.M.M., Rahman M.S., Rahman, M.M. Chowdhury, M.A.H, and Khan, M.S,H. (2003). Effect of tillage practices on soil properties under different cropping patterns. J Sci. Tech, 1:43-48.

[6] Huq, S.M.I. and J.U.M. Shoaib. (2013). The soils of Bangladesh. Worlds Soil Book Series 1,101007/978-94007-128-0.

[7] Huq, S.M.I. and M.D. Alam. (2005). A handbook on analysis of soil, plant and water. Bangladesh-Australia
Centre for Environmental Research (BACER-DU), Dhaka, 31-40 pp.

[8] Huq, S.M.I. and M.D. Alam. (2005). A handbook on analysis of soil, plant and water. Bangladesh-Australia Centre for Environmental Research (BACER-DU), Dhaka, 246 pp.

[9] Islam, M.S., S.A. Mamun, Muliadi, S.Rana, T.R. Tusher and S. Roy. (2015). The impact of brick kiln operation to the degradation of top soil quality of agricultural land,.Agrivita. Journal of Agricultural Science,37(3): 126537.

[10] IUSS (International Union of Soil Sciences). (2002). Soil and the environment, IUSS Commission, World Congress of Soil Science. International Union of Soil Science, 1421 August, Thailand.

[11] Jackson KL.(1962). Soil Chemical Analysis. Preutice Hall of India Pvt. Ltd. New Delhi, p. 498.

[12] Khan, H.R.K. Rahman, A.J.M.A Rouf, G.S. Sattar, Y. Oki and T. Adachi. (2007). Assessment of degradation of agricultural soils arising from brick burning in selected soil profiles. International Journal of Environmental Science and Technology4 (4): 471-480.

[13] Page AL, Miller RH, Keeney DR (1982).Methods of soil Analysis. Part 2. 2nd Ed. American Society of Agronomy, Inc., 677 South Segoe Road, Madison, Wisconsin, USA.

[14] Prabpai, S., L. Chareentanyarak, B. Siri and M.R. (2007). Agronomic properties and Heavy Metals Content in Soil Reclaimed from Municipal Solid Waste Landfill Development of a Knowledge-based system for Foundry Waste Recycling, Journal of Solid Waste Technology and Management, 33(2): 125-150

[15] Rahman, M. (2012). Brickfield. Banglapedia. National Encyclopedia of Bangladesh. Asiatic Society of Bangladesh.

[16] Rahman, M.K. and H.R. Khan. (2001). Impacts of brick kiln on topsoil degradation and environmental pollution. Research Project Report. Ministry of Science, Information and Communication Technology. Bangladesh, $210 \mathrm{pp}$.

[17] Roberts, S., R.V. Vodraska, M.D. Kauffman, and E.H. Gardner. (1971). Methods of Soil Analysis Used in the Soil Testing Laboratory at Oregon State University (Special Report), 321 pp.

[18] Sarkar, M.A.W., S.A. Lira, A. Razzaque, and M.R.H. Sarker. (2016). Comparison of soil nutrients status between an agricultural land close by brickfield and a productive agricultural land for agricultural activities in sadar upazila, Sherpur, Bangladesh. Journal of Soil Nature, 9(1): 8-12.

[19] Satter, D.M.A. and M.M. Rahman. (1987). Techniques of soil Analysis. Department of soil science, Bangladesh Agricultural University, Mymensingh, 67-124 pp.

[20] Singh, R.N., R.N.P. Singh and D.P.S Diwakar. (2000). Characterization of old alluvial soils of some basins of Bihar, Journal of Indian Social Soil Science, 48(20): 352357. 
[21] SRDI (Soil Resource Development Institute). (2018). Land and soil resources Utilization Guide (In Bengali).Upazila Nirdeshica Series-Nagorpur Upazila, Soil Resources Development Institute, Dhaka..

[22] Tucker, M.R., J.K. Messick, and C. Stokes.(1995). Soil fertility note 14: Topsoil. North Carolina Department of Agriculture and Consumer Services (NCDA \& CS). NCDA \&CS Agronomic division. USA, 1-2 pp.

[23] Williams CH, Steinbergs A (1959) Soil sulphur fractions and chemical indices of available sulphur in some Australian soils. Australian J. Agric. Res., 10, 340-352. 